\title{
PATTERNS OF MEDICINE USE IN PATIENTS OF COMMON RESPIRATORY DISEASES TREATED IN THE DEPARTMENT OF PEDIATRICS OF BSMMU HOSPITAL
}

\author{
SWARMITA AFREEN ${ }^{1}$, MD SAYEDUR RAHMAN ${ }^{2}$ \\ ${ }^{1}$ Department of Pharmacology, Bangabandhu Sheikh Mujib Medical University, Shahbag, Dhaka, Bangladesh \\ ${ }^{2}$ Professor, Department of Pharmacology, Bangabandhu Sheikh Mujib Medical University, Shahbag, Dhaka, Bangladesh
}

\begin{abstract}
The present study had attempted to evaluate the medicine use pattern in selected respiratory diseases treated in the Department of Pediatrics of Bangabandhu Sheikh Mujib Medical University (BSMMU) Hospital.

An observational cross sectional study was conducted in the department of Pediatrics, Bangabandhu Sheikh Mujib Medical University (BSMMU) between January 2012 to June 2013. Retrospective prescribing data of sixty cases of bronchiolitis and childhood pneumonia and thirty cases of bronchial asthma was collected from the Record Room and reviewed for inclusion. Then the included treatment records were reviewed and appraised thoroughly. Information regarding patient profile, clinical diagnosis and detail information about medicine was documented in an audit form.
\end{abstract}

Average number of medicine was 3.84, 4.31 and 4.47 in bronchial asthma, bronciholitis and pneumonia respectively and 4.28 for respiratory diseases. Generic prescribing was $12.46 \%$ for department of Pediatrics. Antimicrobials were used in 90.00, 96.66 and 100.00 percent cases of bronchial asthma, bronchiloitis and pneumonia respectively. In case of pneumonia, highest prescribed antimicrobial was Ceftriaxone. Intravenous and oral steroids were used in 63.33, 26.66 and 0.00 percent cases of bronchial asthma, bronchiloitis and pneumonia respectively. Wide variation was observed with medicine selection in different respiratory diseases treated in the department of Pediatrics of BSMMU.

Appropriateness of prescribing cannot be ascertained by medicine use study only. It was revealed that lots of diversity was present in the treatment or selection of medicine. Detail study using newer and comprehensive method and indicators may provide better understanding about prescribing, which might be beneficial to formulate interventions.

Keywords: Medicine use in Pediatrics; university hospital

(Bangladesh J Physiol Pharmacol 2014;30(2):9-13)

\section{INTRODUCTION}

Efforts have increased to improve medicine use since 1985 particularly in developing countries. Subsequent efforts have included a search for standardized methodologies to study medicine use, as well as cost effective interventions. ${ }^{1}$ The indicators recommended for this purpose were tested in different parts of the world. $^{2}$ Four types of intervention strategies identified to improve medicine use, which are as follows, educational, managerial, financial and regulatory. ${ }^{3}$

The provision of medicines is the most challenging issue of primary health care. Every country encounters enormous difficulties in ensuring adequate supply of

Address for correspondence: Dr. Shammin Haque, Assistant Professor, Department of Pharmacology, Dr. Sirajul Islam Medical College and Hospital, Dhaka. E mail: shammin_549@yahoo.com medicine. ${ }^{4}$ A National Drug Policy was introduced in Bangladesh in 1982, which was primarily targeted towards developing the self-reliance in the pharmaceutical production capability of the country as well as ensure availability of essential drugs at an affordable price. ${ }^{5}$ Consequently, production, quality and availability of drug have improved to great extent. ${ }^{6}$ However, the rational use of medicines has not improved in an expected rate till 1985. The milestone regarding rational use of medicine was the conference of experts on Rational Use of Drugs in Nairobi in 1985. ${ }^{7}$ Irrationalities in different aspects of prescribing have been revealed. ${ }^{2,8}$ Many studies were conducted in Bangladesh that produced evidences of different categories of irrationalities at different level of facilities. ${ }^{9-13}$ Different interventions like educational, managerial and regulatory interventions were attempted 
in order to improve medicine use..$^{3,11,12}$ In Bangladesh this was revealed with great surprise that physician used to follow international treatment guideline than national and institutional guideline. ${ }^{14}$ The feature reflects better acceptance of International guideline by the prescribers of Bangabandhu Sheikh Mujib Medical University than that of the institutional and national. American pediatricians also found to have followed clinical practice guideline at a mentionable rate. ${ }^{15}$ In spite of high awareness of prescribers about the guideline, their poor adherence reiterated the gap between prescriber's knowledge and practice. ${ }^{14,16}$ There was significant variation in extent of adherence in different age group of patients, diseases and categories of guidelines. ${ }^{14}$

In Bangladesh, at the teaching hospital level, respiratory diseases were highest among pediatric patients. ${ }^{9,17-19}$ Therefore, the patterns of medicine prescribed in treating different respiratory diseases in pediatric patients were needed to be studied adequately. Accordingly, the present study had attempted to evaluate the pattern of medicine use in treating selected common respiratory diseases treated in Bangabandhu Sheikh Mujib Medical University (BSMMU). BSMMU is the only medical university of our country offering postgraduate medical degrees, therefore understanding about medicine prescribing at this level might provide insight to formulate effective intervention for improving prescribing in Bangladesh.

\section{MATERIALS AND METHODS}

This is an observational cross sectional study, which was conducted in the department of Pediatrics, Bangabandhu Sheikh Mujib Medical University (BSMMU) with collaboration of the department of Pharmacology. The retrospective prescribing data was collected from the Record Room of the BSMMU. Total duration of the study was from January 2012 to June 2013. Ethical issues of this study was reviewed and approved by Institutional Review Board of Bangabandhu Sheikh Mujib Medical University.

In this study, total three diseases of children like bronchiolitis, bronchial asthma and childhood pneumonia treated in the departments of Pediatrics were selected to be studied. Treatment records of individual cases containing clinical diagnosis of selected diseases were considered as sample and samples were collected by consecutive sampling method. Treatment sheet containing more than two diagnoses, documented as discharged on request, absconded and expired were excluded from this study. Sixty treatment sheets of bronchiolitis and childhood pneumonia and thirty of bronchial asthma were included in the study. ${ }^{20}$

\section{Data collection}

A retrospective study was conducted by evaluating the treatment sheets conserved in the record room. The trade name of the medicine commonly prescribed in the selected diseases was checked and memorized by the researcher using Bangladesh National Formulary ${ }^{21}$ and the website of the Directorate General of Drug Administration, www.dgda.gov.bd.

Data collection started from the most recently registered in-patient records to gradually backward manner. The treatment records of the selected disease in the register were initially identified. Then the treatment sheets were reviewed for the inclusion and exclusion criteria to be included in the study. After inclusion, the treatment record of the selected disease was reviewed. Initially an ID was provided at top of the front page of the treatment sheet where confirmed clinical diagnosis and patient profile were mentioned. The following information were documented in review form: serial number of the prescription, date of the prescription, name of medicines in generic name (whether prescribed as generic or in trade name), formulation of medicines (either tablet or capsule or injections or inhaler or syrup or suspension or suppository), route of medicine administration, duration of hospital stay and number of medicines per prescription.

Finally, after inclusion of the cases, information regarding confirmed clinical diagnosis, patient profile, records of prescribing and detail information of medicine was documented in an audit form. The remaining part of the prescription was not studied in this study.

\section{Analysis}

Appropriate statistical test (ANOVA, Z-test of proportion etc) was done in this study for drawing an effective conclusion. Statistical analysis was done with the help of online statistical analysis calculator and Microsoft Office Excel.

\section{RESULTS}

Table I showed that average number of medicine prescribed bronchial asthma patients were 3.84, which were 4.31 and 4.47 for bronciholitis and pneumonia respectively, which was 4.28 for children with respiratory diseases. Prescribing in generic name was $11.35 \%, 15.14 \%$ and $10.52 \%$ for bronchial asthma, bronciholitis and pneumonia respectively and was $12.46 \%$ for department of Pediatrics. The remaining medicines $(87.54 \%)$ were mentioned in prescription in trade name. 
Table I

Pattern of Medicine Prescribed in the Treatment of Different Respiratory Diseases in the Department of Pediatrics

\begin{tabular}{|l|l|l|l|}
\hline $\begin{array}{l}\text { Name of } \\
\text { disease }\end{array}$ & $\begin{array}{l}\text { Average } \\
\text { number of } \\
\text { medicine } \\
\text { per } \\
\text { prescription }\end{array}$ & $\begin{array}{l}\text { Percentage } \\
\text { of drug } \\
\text { prescribed } \\
\text { in generic } \\
\text { name }\end{array}$ & $\begin{array}{l}\text { Percentage } \\
\text { of drug } \\
\text { prescribed } \\
\text { in trade } \\
\text { name }\end{array}$ \\
\hline $\begin{array}{l}\text { Bronchial } \\
\text { asthma } \\
(n=30)\end{array}$ & $\begin{array}{l}3.84 \\
(115 / 30)\end{array}$ & $\begin{array}{l}11.35 \% \\
(13 / 115)\end{array}$ & $\begin{array}{l}88.64 \% \\
(102 / 115)\end{array}$ \\
\hline $\begin{array}{l}\text { Bronchiolitis } \\
(n=60)\end{array}$ & $\begin{array}{l}4.31 \\
(259 / 60)\end{array}$ & $\begin{array}{l}15.14 \% \\
(39 / 259)\end{array}$ & $\begin{array}{l}84.85 \% \\
(220 / 259)\end{array}$ \\
\hline $\begin{array}{l}\text { Pneumonia } \\
(n=60)\end{array}$ & $\begin{array}{l}4.47 \\
(268 / 60)\end{array}$ & $\begin{array}{l}10.52 \% \\
(28 / 268)\end{array}$ & $\begin{array}{l}89.47 \% \\
(240 / 268)\end{array}$ \\
\hline $\begin{array}{l}\text { Total in } \\
\text { Pediatrics } \\
\text { (n=150) }\end{array}$ & $\begin{array}{l}4.28 \\
(642 / 150)\end{array}$ & $\begin{array}{l}12.46 \% \\
(80 / 642)\end{array}$ & $\begin{array}{l}87.54 \% \\
(562 / 642)\end{array}$ \\
\hline
\end{tabular}

Table II showed that $90 \%$ of the bronchial asthma patients received Salbutamol and antibiotic, followed by different steroids. Different oral form of medicines including Montelukast (23.33\%) and Theophyline $(10.00 \%)$ were prescribed and intravenous Dexamethasone $(3.33 \%)$ was the least prescribed medicine.

Table II

Pattern of Medicine Prescribed in the Treatment of Bronchial Asthma in the Department of Pediatrics

\begin{tabular}{|l|l|l|}
\hline $\begin{array}{l}\text { Medicine } \\
\text { prescribed }\end{array}$ & $\begin{array}{l}\text { Route \& } \\
\text { Form }\end{array}$ & $\begin{array}{l}\text { Numberof cases(n= 30) } \\
\text { Expressed in percentage } \\
\text { (\%) }\end{array}$ \\
\hline $\begin{array}{l}\text { Salbutamol } \\
\text { Normal saline }\end{array}$ & Nebulization & $90 \%(27 / 30)$ \\
\hline Antimicrobials & I/V, Oral & $90 \%(27 / 30)$ \\
\hline Beclomethasone & Inhaler & $46.66 \%(14 / 30)$ \\
\hline Hydrocortisone & I/V & $30 \%(09 / 30)$ \\
\hline Prednisolone & Oral & $30 \%(09 / 30)$ \\
\hline Salbutamol & Oral & $23.33 \%(07 / 30)$ \\
\hline Montelucast & Oral & $23.33 \%(07 / 30)$ \\
\hline Anti-histamine & Oral & $16.66 \%(05 / 30)$ \\
\hline Theophylline & Oral & $10 \%(03 / 30)$ \\
\hline
\end{tabular}

\begin{tabular}{|l|l|l|}
\hline $\begin{array}{l}\text { Salbutamol+ } \\
\text { Ipratropium } \\
\text { bromide }\end{array}$ & Nebulization & $06.66 \%(02 / 30)$ \\
\hline Salbutamol & Inhaler & $06.66 \%(02 / 30)$ \\
\hline Levosalbutamol & Inhaler & $06.66 \%(02 / 30)$ \\
\hline Dexamethasone & I/V & $03.33 \%(01 / 30)$ \\
\hline
\end{tabular}

Table III showed that more than $90 \%$ of the bronchiolitis patients received intravenous antimicrobial (96/66\%) followed by Salbutamol as nebulizer (95.00\%) and normal saline (65.00\%). Different oral forms of medicines including anti-histamine (13.33\%) and Salbutamol (11.66\%) were prescribed. Theophyline, both intravenous $(8.33 \%)$ and oral $(8.33 \%)$ was the least prescribed medicine.

Table III

Pattern of Medicine Prescribed in the Treatment of Bronchiolitis in the Department of Pediatrics

\begin{tabular}{|l|l|l|}
\hline $\begin{array}{l}\text { Medicine } \\
\text { prescribed }\end{array}$ & $\begin{array}{l}\text { Route \& } \\
\text { Form }\end{array}$ & $\begin{array}{l}\text { Number of cases (n= } \\
\text { 60) } \\
\text { Expressed in } \\
\text { percentage(\%) }\end{array}$ \\
\hline Antimicrobials & I/V & $96.66 \%(58 / 60)$ \\
\hline Salbutamol & Nebulization & $95 \%(57 / 60)$ \\
\hline $\begin{array}{l}\text { Normal saline nasal } \\
\text { drop }\end{array}$ & Nasal & $65 \%(39 / 60)$ \\
\hline Steroid & I/V, Oral & $26.66 \%(16 / 60)$ \\
\hline Anti-histamine & Oral & $13.33 \%(08 / 60)$ \\
\hline Salbutamol & Oral & $11.66 \%(07 / 60)$ \\
\hline Theophylline & Oral & $08.33 \%(05 / 60)$ \\
\hline $\begin{array}{l}\text { Ipratropium } \\
\text { bromide+Salbutamol }\end{array}$ & Nebulization & $08.33 \%(05 / 60)$ \\
\hline Theophylline & I/V & $08.33 \%(05 / 60)$ \\
\hline
\end{tabular}

Table IV showed that only $20.00 \%$ of the childhood pneumonia patients received single antimicrobial and remaining $(80.00 \%)$ received either combination of antimicrobials or started with one and then switched over to another. Of the single antimicrobial prescribed, $16.66 \%$ patients received Ceftriaxone followed by Cefixime (1.66\%) and Ceftazidime (1.66\%). Of the combination and switch over cases, Ceftriaxone and Amikacin topped the list (21.66\%) followed by Ampicillin and Gentamicin (18.33\%) and Ceftriaxone and Gentamicin (16.66\%) combinations. 
Table IV

Pattern of Antimicrobials Prescribed in the Treatment of Childhood pneumonia in the Department of Pediatrics

\begin{tabular}{|c|c|c|}
\hline Medicine prescribed & $\begin{array}{l}\text { Route } \\
\& \\
\text { Form }\end{array}$ & $\begin{array}{l}\text { Number of cases ( } n= \\
60) \\
\text { Expressed in percentage } \\
(\%)\end{array}$ \\
\hline $\begin{array}{l}\text { Single antimicrobial } \\
(n=12)\end{array}$ & & $20.00 \%(12 / 60)$ \\
\hline Ceftriaxone & $\mathrm{I} / \mathrm{V}$ & $16.66 \%(10 / 60)$ \\
\hline Cefixime & Oral & $01.66 \%(1 / 60)$ \\
\hline Ceftazidime & $\mathrm{I} / \mathrm{V}$ & $01.66 \%(1 / 60)$ \\
\hline $\begin{array}{l}\text { Mixed up of } \\
\text { combination } \quad \& \\
\text { switch over }(n=48)\end{array}$ & & $80.00 \%(48 / 60)$ \\
\hline Ceftriaxone + Amikacin & $\mathrm{I} / \mathrm{V}$ & $21.66 \%(13 / 60)$ \\
\hline $\begin{array}{l}\text { Ampicillin } \\
\text { Gentamicin }\end{array}$ & $\mathrm{I} / \mathrm{V}$ & $18.33 \%(11 / 60)$ \\
\hline $\begin{array}{l}\text { Ceftriaxone } \\
\text { Gentamicin }\end{array}$ & $\mathrm{I} / \mathrm{V}$ & $16.66 \%(10 / 60)$ \\
\hline $\begin{array}{l}\text { Ampicillin } \\
\text { Gentamicin \& } \\
\text { Ceftriaxone } \\
\text { Gentamicin }\end{array}$ & $\mathrm{I} / \mathrm{V}$ & $03.33 \%(2 / 60)$ \\
\hline $\begin{array}{l}\text { Ceftriaxone } \\
\text { Cloxacillin }\end{array}$ & $\mathrm{I} / \mathrm{V}$ & $01.66 \%(1 / 60)$ \\
\hline Ampicillin + Cloxacillin & $\mathrm{I} / \mathrm{V}$ & $01.66 \%(1 / 60)$ \\
\hline Ampicillin + Amikacin & $\mathrm{I} / \mathrm{V}$ & $01.66 \%(1 / 60)$ \\
\hline $\begin{array}{l}\text { Ceftazidime } \\
\text { Amikacin }\end{array}$ & $\mathrm{I} / \mathrm{V}$ & $01.66 \%(1 / 60)$ \\
\hline $\begin{array}{l}\text { Cefixime } \\
\text { Clarithromycin }\end{array}$ & $\mathrm{I} / \mathrm{V}$ & $01.66 \%(1 / 60)$ \\
\hline $\begin{array}{l}\text { Ampicillin } \\
\text { Gentamicin } \\
\text { Clarithromycin }\end{array}$ & $\mathrm{I} / \mathrm{V}$ & $01.66 \%(1 / 60)$ \\
\hline $\begin{array}{l}\text { Ceftriaxone } \\
\text { Gentamicin \& } \\
\text { Ceftriaxone } \\
\text { Flucloxacillin } \\
\end{array}$ & $\begin{array}{l}\text { I/V, } \\
\text { Oral }\end{array}$ & $01.66 \%(1 / 60)$ \\
\hline $\begin{array}{l}\text { Ceftriaxone } \\
\text { Gentamicin } \\
\text { Flucloxacillin }\end{array}$ & $\mathrm{I} / \mathrm{V}$ & $01.66 \%(1 / 60)$ \\
\hline $\begin{array}{l}\text { Ceftriaxone } \\
\text { Gentamicin } \\
\text { Ciprofloxacin } \\
\end{array}$ & $\begin{array}{l}\mathrm{I} / \mathrm{V} \\
\text { Oral }\end{array}$ & $01.66 \%(1 / 60)$ \\
\hline $\begin{array}{l}\text { Ceftriaxone } \\
\text { Gentamicin \& Cefixime }\end{array}$ & $\begin{array}{l}\mathrm{I} / \mathrm{V} \\
\text { Oral }\end{array}$ & $01.66 \%(1 / 60)$ \\
\hline $\begin{array}{l}\text { Ceftriaxone } \\
\text { Gentamicin \& } \\
\text { Meropenem } \\
\text { Gentamicin }\end{array}$ & $\mathrm{I} / \mathrm{V}$ & $01.66 \%(1 / 60)$ \\
\hline
\end{tabular}

\begin{tabular}{|lr|l|l|}
\hline Cefixime, & Ceftriaxone & I/V & $01.66 \%(1 / 60)$ \\
+ & Gentamicin, & & \\
Ceftriaxone ren & + & & \\
Gentamicin & + & & \\
Flucloxacillin & & \\
Ceftriaxone & + & & \\
Flucloxacillin & & & \\
\hline
\end{tabular}

\section{DISCUSSION}

Clinical decisions are based on scientific medical knowledge as well as personal experience of the practicing physician, although a large gap remains between what we know and what we practice. ${ }^{16}$

The present study showed that average number of medicine is higher than previous studies in primary care $^{8}$, pediatricians in private practice ${ }^{10}$ and pediatricians in outpatients of hospitals ${ }^{22}$. Generic prescribing is also lower than previous studies. ${ }^{8,10,22}$

The present study revealed that in case of pediatric asthma patients, ninety percent patients received Salbutamol and normal saline as nebulizer. Equal proportion of patients also received antimicrobials, which appears high, though the prescribing could not be evaluated for rationality as the required criteria for prescribing antimicrobials were not properly mentioned in the treatment sheet. Inhaler Beclomethasone was the preferred steroid preparation. Prescribing oral antihistamine was observed, though reason of prescribing could not be correlated because of inadequate documentation. Different medications prescribed indicating diversity in management of a common disease in a comprehensive setting, like other countries. ${ }^{23,24}$

In case of bronchiolitis, $96.66 \%$ of patients were prescribed antimicrobial, perhaps due to suspicion of pneumonia and bacterial co-infections. Most of the brochiolitis cases $(95.0 \%)$ received nebulized salbutamol with oxygen inhalation as standard treatment, however other medicines were also found in the treatment sheet.

In childhood pneumonia, most of the prescriptions contain combination antimicrobials $(80 \%)$ possibly because of delayed referral or complicated cases were admitted in this hospital. Ceftriaxone was preferred both for cases received single and combinations antimicrobials, reflecting the concern of the prescribers regarding severity of the disease. This was previously reported as a variation in selection of medicines. ${ }^{14}$

Different studies revealed increased number of medicines in prescription, which were linked to less objectivity in medical education as well as inadequate policy and regulations. ${ }^{25-28}$ Couple of interventions were attempted to improve prescribing and role of Pharmacologists were redefined. ${ }^{11-13,29-30}$

Actually it is difficult to conclude about the appropriateness of prescribing by this type of medicine 
use study only. Complicated patients were admitted in this hospital and sufficient document about clinical feature was not present in most of the treatment sheet. However, from this study, it was revealed that lots of diversity was present in the treatment or selection of medicine. Though the present medicine use study was a preliminary one, detail study using newer and detail method and indicators may provide better understanding about prescribing, which might be beneficial to formulate interventions.

\section{REFERENCES}

1. Arhinful DK, Das AM, Hadiyono JP, Heggenhougen $\mathrm{K}$, Higginbotham N, Iyun FB, Quick J, Degnan DR. How to use applied qualitative methods to design drug use interventions, INRUD social scientist working group, Massachusetts, USA; 1996.

2. Hogerzeil HV. Field tests for rational drug use in twelve developing countries. Lancet 1993; 342: 1408-10.

3. Quick JD, Laing RO, Ross-Degnan DG. Intervention research to promote clinically effective and economically efficient use of pharmaceuticals: the International network for Rational Use of drugs. Journal of clinical Epidemiology, 1991; 44: 57-65.

4. World Health Organization (WHO). World Medicine Situation Report 2011. $3^{\text {rd }}$ Edition, World Health Organization, Geneva, Switzerland, 2012.

5. Chowdhury Z. The Politics of Essential Drugs. Zed Books Ltd, London and New Jersey; 1995.

6. Chetley A. From Policy to Practice: The Future of Bangladesh National Drug Policy. IOCU, Penang Malaysia; 1992.

7. Laing RO. Rational drug use: an unsolved problem. Trop Doctor 1990; 20: 101-103.

8. Guyon AB, Barman, Ahmed JU, Ahmed AU, Alam MS. A baseline survey on use of drugs at the primary health care level in Bangladesh. Bull of WHO. 1994; 72: 265-71.

9. Ali L, Chowdhury SAR. Study of Drug Utilization Pattern at a Teaching Hospital. Bangladesh J Physiol Pharmacol 1993; 9: 2728.

10. Rahman MS, Begum M, Khan IA, Chowdhury S, Islam AMZ, Sultana R, Hoque MZ, Akhter N. A Baseline Survey on the Use of Drugs at Private Practitioner Level in Bangladesh. Bangladesh J Physiol Pharmacol 1998; 14: 47-50.

11. Islam MS, Rahman MS, Misbahuddin M. Impact of 'Prescription Audit \& Feedback' on Pattern of Prophylactic Antimicrobials in Caesarean Section: a Cost Reduction Perspective. Bangladesh J Physiol Pharmacol 2007; 23: 1-9.

12. Chowdhury AK, Rahman MS, Faroque AB, Hasan GA, Raihan SZ. Excessive Use of Avoidable Therapeutic Injections in the Upazilla Health Complexes of Bangladesh. Mym Med J 2008; 17(2 Suppl): S59-64.

13. Das AK, Rahman MS. Prescribing vitamins at primary health care level: Exploration of facts, factors and solution. Bangladesh J Pharmacol. 2010; 5: 92-97.

14. Afreen S, Rahman MS. Adherence to treatment guidelines in a university hospital: Exploration of facts and factors. Bangladesh J Pharmacol 2014; 9: 182-88.

15. Christakis DA, Rivara FP. Pediatricians' Awareness of and Attitudes About Four Clinical Practice Guidelines. Pediatrics 1998; 101: 825-30.

16. Sackett DL, Rosenberg WMC, Gray JAM, Haynes RB, Scott W. Evidence based medicine: what it is and what it isn't. Br Med J 1996; 312: 71-72.
17. Rashid HU, Choudhury SAR, Islam N. Pattern of antibiotic use in two teaching hospital. Trop Doctor 1986; 16: 152.

18. Director General of Health Services (DGHS), 2013. Health Bulletin 2012.2 Available http://dghs.gov.bd/bn/licts_file/images/Health_Bulletin/HealthBul letin2012_en.php accessed on 27th September 2014

19. Momen A, Choudhury SAR, Anwar AKMN. Study of the Extent and Pattern of Antibiotic use in the Management of Clinically Diagnosed cases of Common Cold and Fever in Some Selected Government and Private Teaching Hospitals. Bangladesh J Physiol Pharmacol 1999;15(2):67-69.

20. World Health Organization (WHO). How to investigate drug use in health facilities: selected drug use indicators. Geneva, World Health Organization; 1993.

21. Directorate General of Drug Administration (DGDA), Bangladesh Medical Association (BMA), Bangladesh Pharmaceutical Society (BPS), 2006. Bangladesh National Formulary, Dhaka.

22. Mirza NY, Desai S, Ganguly B. Prescribing pattern in a pediatric out-patient department in Gujarat. Bangladesh J Pharmacol. 2009; 4: 39-42.

23. Sanders TR, Roberts CL, Gilbert GL. Compliance with a protocol for intrapartum antibiotic prophylaxis against neonatal group $B$ streptococcal sepsis in women with clinical risk factors. Infect Dis Obs Gyn 2002; 10: 223-9.

24. Rastogi D, Shetty A, Neugebauer R, Harijith A. National Heart, Lung, and Blood Institute guidelines and asthma management practices among inner-city pediatric primary care providers. Chest 2006; 129: 619-23.

25. Rahman MS. Changes Required in Pharmacotherapy Teaching to Ensure Rational Use of Drugs. Bangladesh J Physiol Pharmacol 1995; 11: 38-39.

26. Begum M, Rahman MS, Islam AFMS, Khan IA, Akhter N. Eleven Years of the Undergraduate Medical Curriculum 1988: Review on the Changes in Pharmacology Written Questions. Bangladesh J Physiol Pharmacol 1999: 15: 27-30.

27. Mirza NY, Desai S, Ganguly B. Prescribing pattern in a pediatric out-patient department in Gujarat. Bangladesh J Pharmacol 2009; 4: 39-42.

28. Rahman MS, Huda S. Antimicrobial resistance and related issues: An overview of Bangladesh situation. Bangladesh J Pharmacol 2014; 9: 218-24.

29. Hysong SJ, Best RG, Pugh JA. Audit and feedback and clinical practice guideline adherence: Making feedback actionable. Implement Sci 2006; 1: 9.

30. Rahman MS. New global situation in drug regulation: Redefined responsibility of the Pharmacologists of Bangladesh. Bangladesh J Physiol Pharmacol 1999; 15: 41-42. 